\title{
Proteomic analysis of primary duck hepatocytes infected with duck hepatitis $B$ virus
}

\author{
Yanfeng Zhao ${ }^{+1}$, Haijing Ben ${ }^{+1}$, Su Qu+1, Xinwen Zhou², Liang Yan', Bin Xu'1, Shuangcheng Zhou' ${ }^{1}$ Qiang Lou', \\ Rong Ye1, Tianlun Zhou' ${ }^{1}$ Pengyuan Yang ${ }^{2}$ and Di Qu*1
}

\begin{abstract}
Background: Hepatitis B virus (HBV) is a major cause of liver infection in human. Because of the lack of an appropriate cell culture system for supporting HBV infection efficiently, the cellular and molecular mechanisms of hepadnavirus infection remain incompletely understood. Duck heptatitis B virus (DHBV) can naturally infect primary duck hepatocytes (PDHs) that provide valuable model systems for studying hepadnavirus infection in vitro. In this report, we explored global changes in cellular protein expression in DHBV infected PDHs by two-dimension gel electrophoresis (2-DE) combined with MALDI-TOF/TOF tandem mass spectrometry (MS/MS).

Results: The effects of hepadnavirus infection on hepatocytes were investigated in DHBV infected PDHs by the 2-DE analysis. Proteomic profile of PDHs infected with DHBV were analyzed at 24, 72 and $120 \mathrm{~h}$ post-infection by comparing with uninfected PDHs, and 75 differentially expressed protein spots were revealed by 2-DE analysis. Among the selected protein spots, 51 spots were identified corresponding to 42 proteins by MS/MS analysis; most of them were matched to orthologous proteins of Gallus gallus, Anas platyrhynchos or other avian species, including alpha-enolase, lamin A, aconitase 2, cofilin-2 and annexin A2, etc. The down-regulated expression of beta-actin and annexin A2 was confirmed by Western blot analysis, and potential roles of some differentially expressed proteins in the virus-infected cells have been discussed.

Conclusions: Differentially expressed proteins of DHBV infected PDHs revealed by 2-DE, are involved in carbohydrate metabolism, amino acid metabolism, stress responses and cytoskeleton processes etc, providing the insight to understanding of interactions between hepadnavirus and hepatocytes and molecular mechanisms of hepadnavirus pathogenesis.
\end{abstract}

\section{Introduction}

The HBV, prototype of the Hepadnaviridae family, is a noncytopathic hepatotropic DNA virus replicating via reverse transcription [1]. More than 350 million individuals are HBV carriers worldwide and over one-third of them develop serious liver diseases such as chronic hepatitis, cirrhosis and primary hepatocellular carcinoma [2]. Major obstacles in HBV research have been the inability of the virus to infect cells in vitro and lack of adequate animal models for HBV infection, though primary human hepatocytes and HepaRG cell line have been used to

* Correspondence: dqu@shmu.edu.cn

1 Key Laboratory of Medical Molecular Virology of Ministries of Education and Health, Institute of Medical Microbiology and Institutes of Biomedical Sciences, Shanghai Medical College of Fudan University, Shanghai, China + Contributed equally

Full list of author information is available at the end of the article study HBV infection [3]. Human primary hepatocytes and HepaRG cells can support HBV life cycle, but have limitations in accessibility, reproducibility and low level of HBV replication, and a large amount of input virus was needed to infect low proportion of cells [4-6]. DHBV and woodchuck hepatitis B virus (WHBV) are classified into the family of hepadnaviridae. Thus for hepadnavirus infection primary hepatocytes of ducks (DHBV) and woodchucks (WHBV) are still considered as suitable models for investigating the viral replication and pathogenesis $[7,8]$.

The development of proteomic methods has enabled us to investigate the changes of cellular protein expression at a global scale to reveal virus-host interactions [9-12]. The effect of hepadnavirus replication on the host cells, such as the carcinoma derived hepatocyte lines transfected with the HBV genome, HepaRG cell lines or HBV trans- 
genic mice, have been investigated by using 2-DE analysis [13-15]. In the present study, we intend to utilize the DHBV-PDHs system to explore global protein expression changes during hepadnavirus infection by 2-DE. A total of 75 differentially expressed protein spots were revealed by 2-DE between DHBV infected and uninfected PDHs, and 51 protein spots have been identified by MS/MS analysis. Differential expression of beta-actin and annexin A2 was confirmed by Western blot analysis, and potential roles of some differentially expressed proteins in the viral infection have been discussed.

\section{Results}

\section{DHBV infection of PDHs}

PDHs isolated from the same liver of DHBV-negative Cherry Valley duckling were infected with DHBV at multiplicity of infection of 30 (MOI, based on DHBV DNA genome equivalents) and cultured for 12, 24, 72 and $120 \mathrm{~h}$ in L15 medium supplemented with $5 \%$ fetal bovine serum (FBS). The efficiency of DHBV infection in PDHs was determined by indirect immunofluorescence using antiDHBV preS monoclonal antibody. PDHs inoculated with phosphate-buffered saline (PBS, pH 7.2) as a control. At $12 \mathrm{~h}$ and $24 \mathrm{~h}$ after infection, only a few cells showed fluorescence (data not shown), and at $72 \mathrm{~h}$ post-infection about $30 \%$ of cells expressed viral large surface antigen, indicating that cells were infected with DHBV, showed in Figure 1. DHBV DNA in PDHs was analyzed by Southern blot hybridization using an alpha-32P-dCTP labeled DHBV-specific probe, and DHBV in the supernatant was detected by real time polymerase chain reaction (PCR). Single stranded forms of intracellular viral DNA and DHBV copy number increasing in the supernatant indicated the replication of DHBV $72 \mathrm{~h}$ and $120 \mathrm{~h}$ post-infection (Additional File 1 and 2).

\section{2-DE analysis of differentially expressed proteins of DHBV infected PDHs}

Differentially expressed proteins between DHBV infected and uninfected PDHs at 24, 72 and $120 \mathrm{~h}$ post-infection were analyzed using the 2-DE. The gels were stained by a modified silver staining method compatible with mass spectrometry (MS) analysis and processed for image analysis. On the 2-DE gels (pH 3-10 NL, $24 \mathrm{~cm})$, about 1150 1350 protein spots were detected. Compared with the parallel uninfected PDHs, 91 differentially expressed protein spots were revealed by 2 -DE ( $p$-values less than 0.05 with at least a 1.5 -fold difference in percentage of the volume), shown in Figure 2 and Additional File 3 (see also Additional File 4), and a total of 75 differentially expressed non-redundant protein spots were analyzed by MS/MS.

\section{Identification of differentially expressed proteins in DHBV infected PDHs}

Differentially expressed protein spots between DHBV infected and uninfected PDHs, were excised, digested ingel with trypsin and determined by MS/MS. Among 75 differentially expressed protein spots, 51 protein spots were identified corresponding to 42 proteins (Table 1 and Additional File 5). With a MASCOT cutoff score of 72 ( $p$ value less than 0.05), 51 spots were identified, and 37 spots were matched to orthologous proteins of avian species (26 protein spots to Gallus gallus, 4 spots to Anas platyrhynchos and 7 spots to other avian species), listed in Table 1 . Some of the differentially expressed protein spots such as annexin A2, beta-actin, lamin A, destrin, aconitase 2 and $\mathrm{Mn}$ superoxide dismutase were illustrated in enlarged formats (Figure 3), and representative mass spectrum of annexin A2 (spot 49) analyzed by MALDI-TOF/TOF MS was shown in Figure 4. Isoforms of annexin A2, alpha-enolase, lamin A, glyceraldehyde-3phosphate dehydrogenase $(\mathrm{GAPDH})$, heat shock protein 70 (Hsp70) and elongation factor 2 have been identified. For example, protein spot 49 (MW $31 \mathrm{kDa}$ and $\mathrm{p} I$ of 5.45) and spot 50 (MW $10 \mathrm{kDa}$ and $\mathrm{p} I$ of 5.78) down-regulated in DHBV infected PDHs were both identified as annexin $\mathrm{A} 2$, and up-regulated protein spot $26(\mathrm{MW} 65 \mathrm{kDa}$ and $\mathrm{p} I$ of 6.61) and spot 27 (MW $66 \mathrm{kDa}$ and $\mathrm{p} I$ of 6.4) were matched to lamin A (theoretical MW $73.1 \mathrm{kDa}$ and $\mathrm{p} I$ of 6.5) showed in Figure 2.

Biological functions of the differentially expressed proteins in the DHBV-infected PDHs, were analyzed according to the Gene Ontology criteria and classified into carbohydrate metabolism (29\%), amino acid metabolism (14\%), cytoskeletal/structural protein (24\%), stress response (18\%) and other functions (16\%), as shown in Table 1 . The roles of selected differentially expressed proteins reported in viral infections were showed in Table 2.

\section{Validation of differentially expressed proteins}

Expression levels of annexin A2, beta-actin, Hsp70, destrin, and lamin A were validated by Western blot analysis to confirm the dynamic alterations of protein expression during DHBV infection. Equal amounts $(30 \mu \mathrm{g})$ of cell lysates of DHBV-infected and uninfected PDHs at 12, 24, 72 and $120 \mathrm{~h}$ post-infection were separated by SDSPAGE. Duck beta-actin and annexin A2 expression were detected down-regulated in the DHBV-infected PDHs at 12-120 $\mathrm{h}$ post-infection with mouse anti-beta-actin and anti-duck-annexin A2 as primary antibodies (Figure 5A), that were consistent with the protein expression pattern revealed by the 2-DE analysis. Duck Hsp70, destrin, and lamin A were not detected by Western blot analysis with the rabbit anti-human or anti-mouse Hsp70 polyclonal antibodies, rabbit anti-human destrin polyclonal antibody and rabbit anti-human lamin A polyclonal antibody. 
DHBV preS
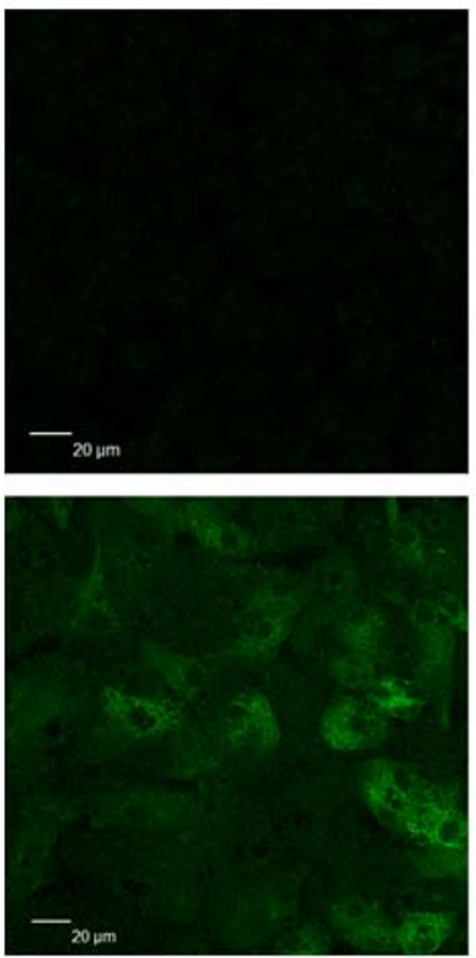

DAPI
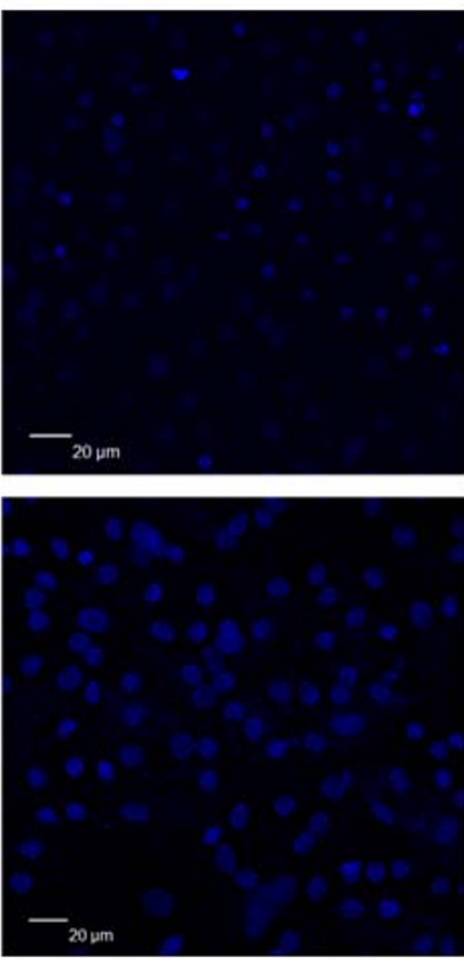

Merge

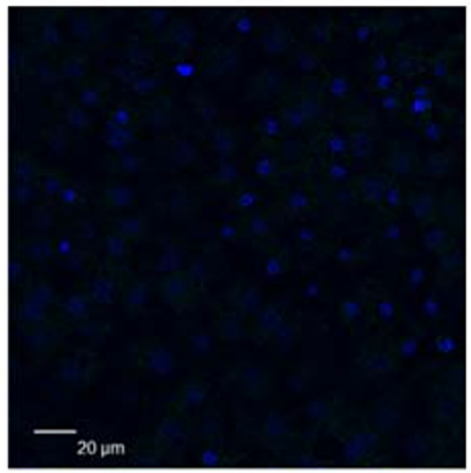

Control

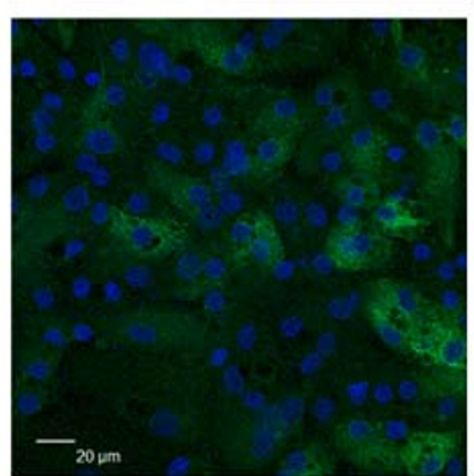

DHBV p.i.72 h

Figure 1 Detection of DHBV infected PDHs by indirect immunofluorescence. PDHs were prepared by liver perfusion and seeded on glass coverslips, and infected with DHBV concentrated from the supernatant of LMH-D2 by ultracentrifugation. PDHs were fixed with $4 \%$ polyoxymethylene. DHBV infected PDHs was detected by indirect immunofluorescence staining with mouse anti-DHBV preS mAb, and followed by goat anti-mouse lgGFITC antibody. Then cells were stained with DAPI and visualized by confocal microscopy (Green, FITC; blue, DAPI). The symbol "p.i." represents DHBV post-infection PDHs.

The same amount protein of each sample were applied to a parallel SDS-PAGE gel and stained with Coomassie brilliant blue (Figure 5B).

\section{Discussion}

HBV infection remains a public health problem worldwide. Because the lack of appropriate cell lines that can support HBV infection efficiently, the cellular and molecular mechanisms of hepadnavirus infection remain incompletely understood. The hepadnavirus animal infection models such as ducks (DHBV) and woodchucks (WHBV) have been used to investigate the viral replication, pathogenesis or hepadnavirus-associated hepatocellular carcinoma. DHBV-PDHs model is a valuable model of hepadnavirus infection with high reproducibility and efficiency [16]. In the present study, global changes in cellular protein expression in DHBV-infected PDHs were explored by 2-DE combined with MS/MS. Among the 75 differentially expressed protein spots, 51 spots have been identified by MS/MS corresponding to 42 proteins, in which 30 spots were matched to orthologous proteins of Gallus gallus or Anas platyrhynchos, 7 spots to other avian species, and 14 spots to non-avian species, while mass spectra of the other 24 protein spots did not match to any proteins in the current databases, possibly due to the incomplete genome sequence of Anas platyrhynchos or low abundance of those protein spots.

In previously studies, Tong performed a proteomic analysis comparing HepG2 with HepG2.2.15 in which HBV genome integrated into cellular chromosome [13], and Narayan revealed 19 differentially regulated features in HepaRG cells by 2-DE [14]. HepG2.2.15 is a HBV replication cell model but not an infection model, while the human hepatoma HepaRG cells are susceptible to HBV, but $10 \sim 20 \%$ of cells can be infected regardless of the amount of virus used (MOI > 200) [4,6]. In previous studies, it has been showed that at MOI of 30 , about $50 \% \sim 60 \%$ PDHs can be reproducibly infected with DHBV [17]. Some of differentially expressed proteins identified in the present study, such as alpha-enolase, lamin A, GAPDH and cofilin-2 have not yet been reported in hepadnavirus proteomic analysis.

Viruses depend on host cell metabolism for their replication. Elucidation of the pathways/processes involving 

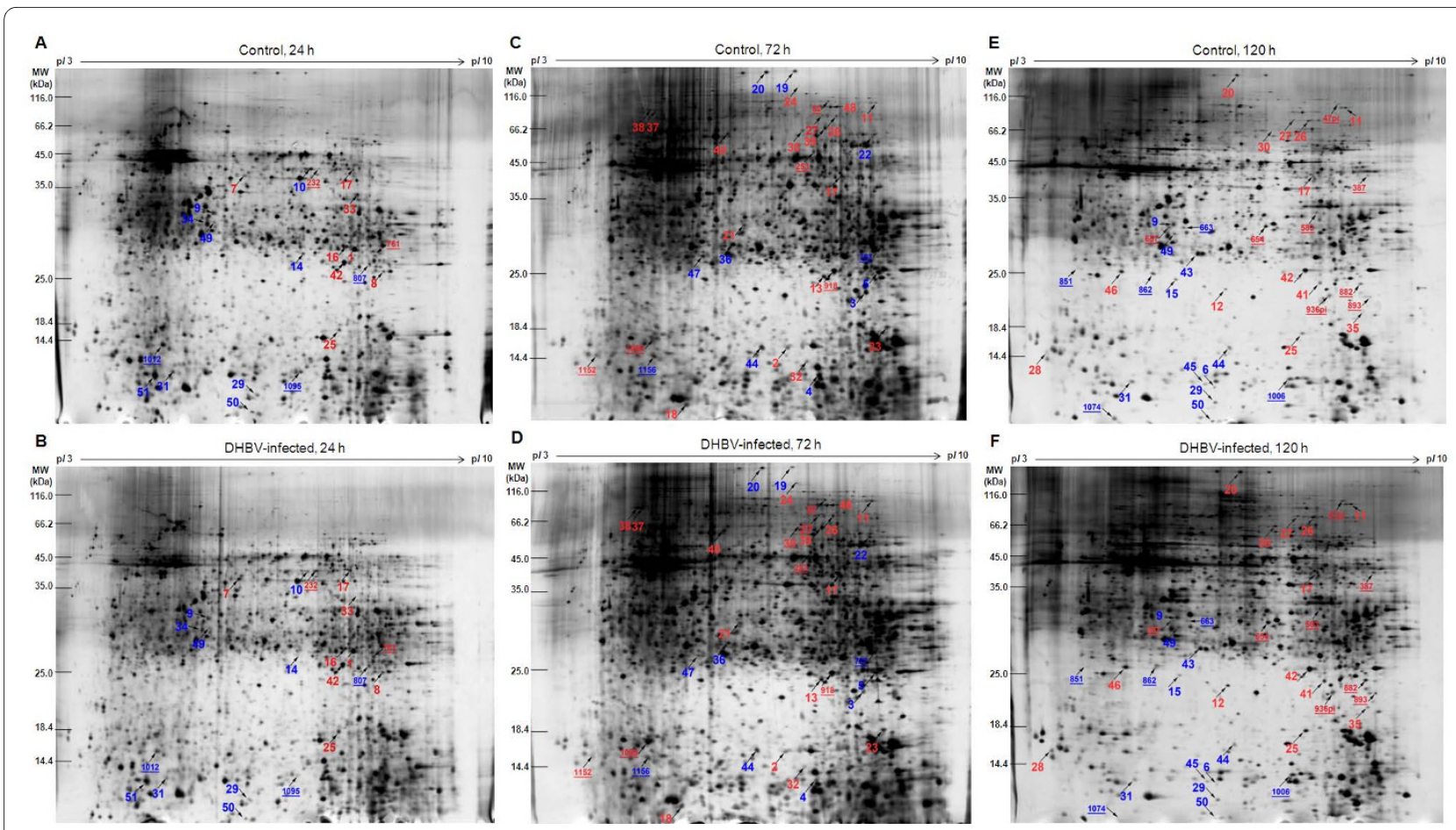

Figure 2 Comparison of 2-DE gel patterns between DHBV infected and uninfected PDHs. Proteins were extracted from DHBV infected and uninfected PDHs at 24, 72 and $120 \mathrm{~h}$ post-infection. Equal proteins (120 $\mathrm{\mu g}$ ) were loaded and separated on the 24-cm pH 3-10 nonlinear IPG strips, followed by $12 \%$ SDS-PAGE gels visualized by silver staining. Differentially expressed protein spots on 2-DE gels were identified by MS/MS analysis and shown in gels with unique protein spot numbers. Gels of B, D, F and A, C, E represent 2-DE gels obtained from DHBV infected and uninfected PDHs at 24, 72 and $120 \mathrm{~h}$ post-infection, respectively. The numbers of unidentified spots are underlined and listed in Additional File 4, the numbers of upregulated protein spots in infected samples are labeled in red and the numbers of down-regulated protein spots in blue color (A $F$ ).

in the viral life cycle will help to understand the mechanisms of viral infection. In the 2-DE analysis, the identified differentially expressed proteins were classified into carbohydrate metabolism, amino acid metabolism, cytoskeletal/structural protein, stress response and other functions according to the Gene Ontology criteria. Some of differentially expressed proteins identified in the present study have been reported playing roles in viral infections, as shown in Table 2.

In DHBV infected PDHs, the expression of some carbohydrate metabolic enzymes, such as phosphoglycerate kinase 1, triosephosphate isomerase, phosphoglycerate mutase 1 etc, was up-regulated. The differentially expressed proteins involving in carbohydrate metabolism, suggests perturbed energy metabolism in DHBV infections. Hepatitis C Virus (HCV) infection reprograms the cellular metabolisms to favor glucose fermentation and glycolytic intermediates toward the metabolite synthesis that supports the viral life cycle [18]. In lymphocytic choriomeningitis virus infection, there was a significant increasing in transcripts promoting gluconeogenesis for viral mediate synthesis, and a decreasing in transcripts promoting glycogenolysis in the early stage of infection [19].
However, GAPDH and alpha-enolase, key enzymes involving in glycolysis and gluconeogenesis, are decreased in DHBV infected PDHs. GAPDH and alphaenolase have been found associating with the cell membrane and in secreted viral particles of influenza virus, lentiviral vector etc $[20,21]$. GAPDH may phosphorylate the HBV core protein, and binds to the preS1 region of the HBV envelope antigen and posttranscriptional regulatory element in regulating expression of surface antigen, suggesting that GAPDH plays an important role in the life-cycle of HBV infection [22-24]. The host cellular carbohydrate metabolism affected by DHBV infection may benefit viral replication.

Alterations of cytoskeleton networks were found in many viral infections [25-27]. Hepadnavirus needs to manipulate and utilize the host cytoskeleton to promote viral infection like many viruses, although the mechanism is still unclear [28]. In DHBV infected PDHs, the microfilament-associated proteins, beta-actin and cofilin-2 were down-regulated, and three microfilament-associated proteins such as transgelin, destrin, and collapsin response mediator protein-2B were up-regulated. Actin plays an active role in maturation of the viruses [29,30]. Many viruses require actin for viral entry and establishment of 


\begin{tabular}{|c|c|c|c|c|c|c|c|c|c|}
\hline \multirow[t]{3}{*}{ Spot No. ${ }^{a}$} & \multirow[t]{2}{*}{ Protein } & \multirow[t]{2}{*}{ Species } & \multirow[t]{2}{*}{ Accession No.b } & \multirow[t]{2}{*}{ MOWSE Scorec } & \multirow[t]{2}{*}{ Tmw/Emwd } & \multirow[t]{2}{*}{ Tp//Ep/e } & \multicolumn{3}{|c|}{ Ratio: infected/uninfected } \\
\hline & & & & & & & $24 \mathrm{~h}$ & $72 \mathrm{~h}$ & $120 \mathrm{~h}$ \\
\hline & Carbohydrate metabolism & & & & & & & & \\
\hline 1 & Triosephosphate isomerase 1 & Gallus gallus & gi|45382061 & 385 & $26.6 / 29$ & $6.71 / 6.62$ & 1.5 & 1 & $\mathrm{~N}^{f}$ \\
\hline 2 & Triosephosphate isomerase & Meleagris gallopavo & gi|34221747 & 99 & $22.5 / 16$ & $6.19 / 6.00$ & 1.4 & 3 & 1 \\
\hline 3 & $\begin{array}{l}\text { Glyceraldehyde-3-phosphate } \\
\text { dehydrogenase(GAPDH) }\end{array}$ & Columba livia & gi|6016077 & 109 & $35.7 / 22$ & $8.71 / 7.41$ & 1 & 0.5 & N \\
\hline 4 & $\begin{array}{l}\text { Glyceraldehyde-3-phosphate } \\
\text { dehydrogenase(GAPDH) }\end{array}$ & Columba livia & gi|6016077 & 102 & $35.7 / 13$ & $8.71 / 6.23$ & 0.66 & 0.2 & $\mathrm{~N}$ \\
\hline 5 & $\begin{array}{l}\text { Glyceraldehyde-3-phosphate } \\
\text { dehydrogenase(GAPDH) }\end{array}$ & Passer domesticus & gi|37698402 & 131 & $34.8 / 25$ & $8.71 / 7.80$ & 1 & 0.5 & N \\
\hline 6 & $\begin{array}{l}\text { Glyceraldehyde-3-phosphate } \\
\text { dehydrogenase(GAPDH) }\end{array}$ & Columba livia & gi|6016077 & 94 & $35.7 / 12$ & $8.71 / 5.79$ & 1 & 1 & 0.2 \\
\hline 7 & Phosphoglycerate kinase 1 & Gallus gallus & gi|45384486 & 231 & $44.7 / 42$ & $8.31 / 5.66$ & 2.5 & 1.5 & 1 \\
\hline 8 & Phosphoglycerate mutase 1 & Gallus gallus & gi|71895985 & 135 & $28.9 / 25$ & 7.03/7.39 & 1.5 & 1.3 & 1 \\
\hline 9 & Alpha-enolase & Anas platyrhynchos & gi|213085 & 124 & $40.8 / 32$ & $6.28 / 5.45$ & 0.66 & 0.8 & 0.5 \\
\hline 10 & Alpha-enolase & Anas platyrhynchos & gi|119338 & 340 & $47.2 / 43$ & $6.37 / 6.12$ & 0.25 & $\mathrm{~N}$ & $\mathrm{~N}$ \\
\hline 11 & Aconitase 2 , mitochondrial & Gallus gallus & gi|45383738 & 227 & $85.7 / 103$ & $8.05 / 7.78$ & N & 2 & 1.8 \\
\hline 12 & ATP5A1 & Taeniopygia guttata & gi|91805309 & 380 & $21.5 / 23$ & $6.4 / 5.85$ & 1.2 & 0.9 & 2.3 \\
\hline 13 & Atp5a1 protein & Xenopus tropicalis & gi|71896075 & 146 & $59.8 / 24$ & $9.13 / 6.47$ & 1.3 & 0.56 & 1 \\
\hline 14 & $\begin{array}{l}\text { Chain E, Chicken Cytochrome Bc1 Complex } \\
\text { Inhibited By An lodinated Analogue Of The } \\
\text { Polyketide Crocacin-D }\end{array}$ & Xenopus tropicalis & gi|196049779 & 146 & $21.5 / 27$ & $6.07 / 6.00$ & 0.17 & $\mathrm{~N}$ & 1 \\
\hline 15 & $\begin{array}{l}\text { similar to ubiquinol--cytochrome } c \\
\text { reductase }\end{array}$ & Gallus gallus & gi|50754375 & 72 & $52.7 / 24$ & $6.58 / 5.45$ & 1 & 1.2 & 0.5 \\
\hline
\end{tabular}

Amino acid metabolism

\begin{tabular}{|c|c|c|c|c|c|c|c|c|c|}
\hline 16 & unnamed protein product & Mus musculus & gi|74183518 & 118 & $35.8 / 28$ & $6.84 / 6.80$ & 1.5 & 1 & 1 \\
\hline 17 & $\begin{array}{l}\text { similar to betaine homocysteine methyl } \\
\text { transferase }\end{array}$ & Gallus gallus & gi|50755288 & 96 & $45 / 44$ & $7.56 / 6.80$ & 1.5 & 2 & 1.5 \\
\hline 18 & Pterin-4 alpha-carbinolamine dehydratase & Gallus gallus & gi|45382483 & 170 & $12.0 / 11$ & $6.04 / 5.42$ & 1 & 1.8 & $\mathrm{~N}$ \\
\hline
\end{tabular}


Table 1: Differentially expressed proteins in DHBV-infected PDHs identified by MALDI-TOF/TOF (Continued)

\begin{tabular}{|c|c|c|c|c|c|c|c|c|c|}
\hline 19 & similar to Urocanase domain containing 1 & Gallus gallus & gi|50754419 & 127 & $75.1 / 149$ & $7.21 / 6.12$ & 1 & 0.5 & 1.2 \\
\hline 20 & similar to Urocanase domain containing 1 & Gallus gallus & gi|50754419 & 99 & $75.1 / 149$ & $7.21 / 5.91$ & 1 & 0.66 & 1.7 \\
\hline 21 & $\begin{array}{l}\text { similar to 3-mercaptopyruvate } \\
\text { sulfurtransferase }\end{array}$ & Gallus gallus & gi|50794693 & 144 & $33.2 / 32$ & $5.66 / 5.80$ & 0.75 & 0.25 & $\mathrm{~N}$ \\
\hline \multirow[t]{2}{*}{22} & Aldehyde dehydrogenase $4 \mathrm{~A} 1$ & Xenopus laevis & gi|148228402 & 99 & $61.7 / 58$ & $8.22 / 7.18$ & $\mathrm{~N}$ & 3 & 1.2 \\
\hline & Cytoskeletal/structural protein & & & & & & & & \\
\hline 23 & Transgelin & Gallus gallus & gi|45382783 & 92 & $22.3 / 19$ & $8.85 / 7.78$ & 1 & 3 & 1.4 \\
\hline 24 & Vinculin & Gallus gallus & gi|45382123 & 82 & $116.9 / 116$ & $6 / 6.12$ & $\mathrm{~N}$ & 3 & 1 \\
\hline 25 & Destrin & Gallus gallus & gi|45382979 & 97 & $18.5 / 18$ & $7.52 / 6.60$ & 1.5 & 1.33 & 2 \\
\hline 26 & Lamin A & Gallus gallus & gi|45384214 & 168 & $73.1 / 65$ & $6.5 / 6.61$ & $\mathrm{~N}$ & 2 & 2 \\
\hline 27 & Lamin A & Gallus gallus & gi|45384214 & 74 & $73.1 / 66$ & $6.5 / 6.40$ & $\mathrm{~N}$ & 1.5 & 2 \\
\hline 28 & $\begin{array}{l}\text { similar to Myosin regulatory light chain } \\
2, \text { nonsarcomeric (Myosin RLC) isoform } 1\end{array}$ & Canis lupus familiaris & gi|73961895 & 241 & $20.5 / 15$ & $4.62 / 3.80$ & 1 & 1 & $\mathrm{~A} / \mathrm{Ng}$ \\
\hline 29 & similar to HSPC162(dynein, light chain) & Gallus gallus & gi|50758587 & 86 & $10.9 / 11$ & $6.58 / 5.79$ & 0.5 & 1 & 0.33 \\
\hline 30 & Collapsin response mediator protein-2B & Gallus gallus & gi|33340025 & 173 & $62.2 / 69$ & $6.05 / 6.12$ & $\mathrm{~N}$ & $\mathrm{~A} / \mathrm{N}$ & 2 \\
\hline 31 & Cofilin-2 & Gallus gallus & gi|17433708 & 74 & $18.6 / 14$ & $7.66 / 5.20$ & 0.33 & 1.2 & 0.67 \\
\hline 32 & Gelsolin & Gallus gallus & gi|45384386 & 95 & $85.8 / 14$ & $5.93 / 6.19$ & $\mathrm{~N}$ & 0.25 & 1 \\
\hline 33 & similar to LIM protein & Danio rerio & gi|68371150 & 84 & $35.1 / 37$ & $6.2 / 6.61$ & $\mathrm{~N} / \mathrm{A}^{\mathrm{g}}$ & 1.3 & 1 \\
\hline 34 & beta-actin & Labeo calbasu & gi|18034011 & 343 & $41.7 / 41$ & $5.16 / 5.40$ & 0.63 & 0.8 & 0.94 \\
\hline
\end{tabular}

\section{Stress response}

\begin{tabular}{|c|c|c|c|c|c|c|c|c|c|}
\hline 35 & $\begin{array}{l}\text { similar to heat shock } 70 \mathrm{kDa} \text { protein } 8 \\
\text { isoform } 2 \text { isoform } 2\end{array}$ & Canis lupus familiaris & gi|74012289 & 74 & $53.5 / 20$ & $5.59 / 7.80$ & $\mathrm{~N}$ & $\mathrm{~N}$ & $\mathrm{~A} / \mathrm{N}$ \\
\hline 36 & $\begin{array}{l}\text { Chain A, T13g Mutant Of The ATPase } \\
\text { Fragment Of Bovine Hsc70 }\end{array}$ & Bos taurus & gi|6729825 & 237 & $41.9 / 29$ & $6.63 / 5.72$ & 0.7 & 0.33 & 1 \\
\hline 37 & Heat shock $70 \mathrm{kDa}$ protein 5 precursor & Gallus gallus & gi|45382769 & 526 & $72 / 96$ & $5.12 / 5.00$ & $\mathrm{~N}$ & $\mathrm{~A} / \mathrm{N}$ & 1 \\
\hline 38 & Heat shock $70 \mathrm{kDa}$ protein 5 precursor & Gallus gallus & gi|45382769 & 471 & $72 / 96$ & $5.12 / 5.00$ & $\mathrm{~N}$ & $\mathrm{~A} / \mathrm{N}$ & 1 \\
\hline 39 & $\begin{array}{l}\text { Chaperonin containing TCP1, subunit } 6 \mathrm{~A} \\
\text { (zeta 1) }\end{array}$ & Gallus gallus & gi|57525300 & 211 & $57.6 / 65$ & $6.36 / 6.60$ & 1 & 2 & 1.3 \\
\hline 40 & $58 \mathrm{kDa}$ glucose regulated protein precursor & Gallus gallus & gi|45383890 & 251 & $56.1 / 62$ & $5.76 / 5.69$ & $\mathrm{~N}$ & 2 & 1 \\
\hline 41 & Mn superoxide dismutase & Cairina moschata & gi|184133036 & 235 & $12.9 / 24$ & $6.39 / 7.00$ & 1 & 1 & 1.71 \\
\hline
\end{tabular}


Table 1: Differentially expressed proteins in DHBV-infected PDHs identified by MALDI-TOF/TOF (Continued)

\begin{tabular}{|c|c|c|c|c|c|c|c|c|c|}
\hline 42 & $\begin{array}{l}\text { similar to antioxidant protein isoform } 2 \\
\text { (peroxiredoxin-3) }\end{array}$ & Sus scrofa & gi|194042134 & 256 & $26.6 / 25$ & $6.79 / 6.80$ & 1.5 & 1.43 & 1.5 \\
\hline \multirow[t]{2}{*}{43} & LOC496089 protein & Xenopus laevis & gi|56269242 & 97 & $29.9 / 28$ & $6.07 / 5.70$ & 1 & 1 & 0.5 \\
\hline & Other functions & & & & & & & & \\
\hline 44 & Elongation factor 2 & Oxyuranus scutellatus & gi|63146080 & 83 & $45.1 / 16$ & $5.83 / 5.85$ & 1 & 0.66 & 0.67 \\
\hline 45 & Elongation factor 2 & Mus musculus & gi|192989 & 140 & $29.9 / 15$ & $6.2 / 5.78$ & 1 & 1 & 0.5 \\
\hline 46 & Cathepsin B & Gallus gallus & gi|46195455 & 73 & $37.6 / 25$ & $5.74 / 5.08$ & 1 & 1 & 1.5 \\
\hline 47 & $\begin{array}{l}\text { ubiquitin carboxyl-terminal esterase L1 } \\
\text { (ubiquitin thiolesterase) }\end{array}$ & Taeniopygia guttata & gi|115391986 & 132 & $25.2 / 28$ & $5.83 / 5.45$ & $\mathrm{~N}$ & 0.29 & 0.85 \\
\hline 48 & Ovotransferrin & Anas platyrhynchos & gi|3024757 & 144 & $75.6 / 91$ & $6.19 / 6.60$ & $\mathrm{~N}$ & 1.5 & 1.3 \\
\hline 49 & Annexin A2 & Gallus gallus & gi|45382533 & 148 & $38.6 / 31$ & $6.92 / 5.45$ & 0.33 & 1 & 0.5 \\
\hline 50 & Annexin A2 & Gallus gallus & gi|45382533 & 204 & $38.6 / 10$ & $6.92 / 5.78$ & 0.5 & N & 0.2 \\
\hline 51 & Annexin A5 & Anoplopoma fimbria & gi|229366222 & 75 & $34.9 / 12$ & $5.28 / 5.00$ & 0.5 & 1 & 0.86 \\
\hline
\end{tabular}

a) Spots numbers correspond to the numbers in Figure 2.

b) Accession no. is the MASCOT result of MALDI-TOF/TOF searched from the NCBInr database.

c) Protein score was from MALDI-TOF/TOF identification. The proteins that had a statistically significant score great than $72(p<0.05)$ were considered identified.

d) Theoretical/experimental molecular mass.

e) Theoretical/experimental molecular $\mathrm{pl}$

f) Not applicable, because the spots on the gels were too weak or non-detectable.

g) A represents the spot on one of the gels was detectable, $\mathrm{N}$ represents the spot on one of the gels was too weak to detect. 


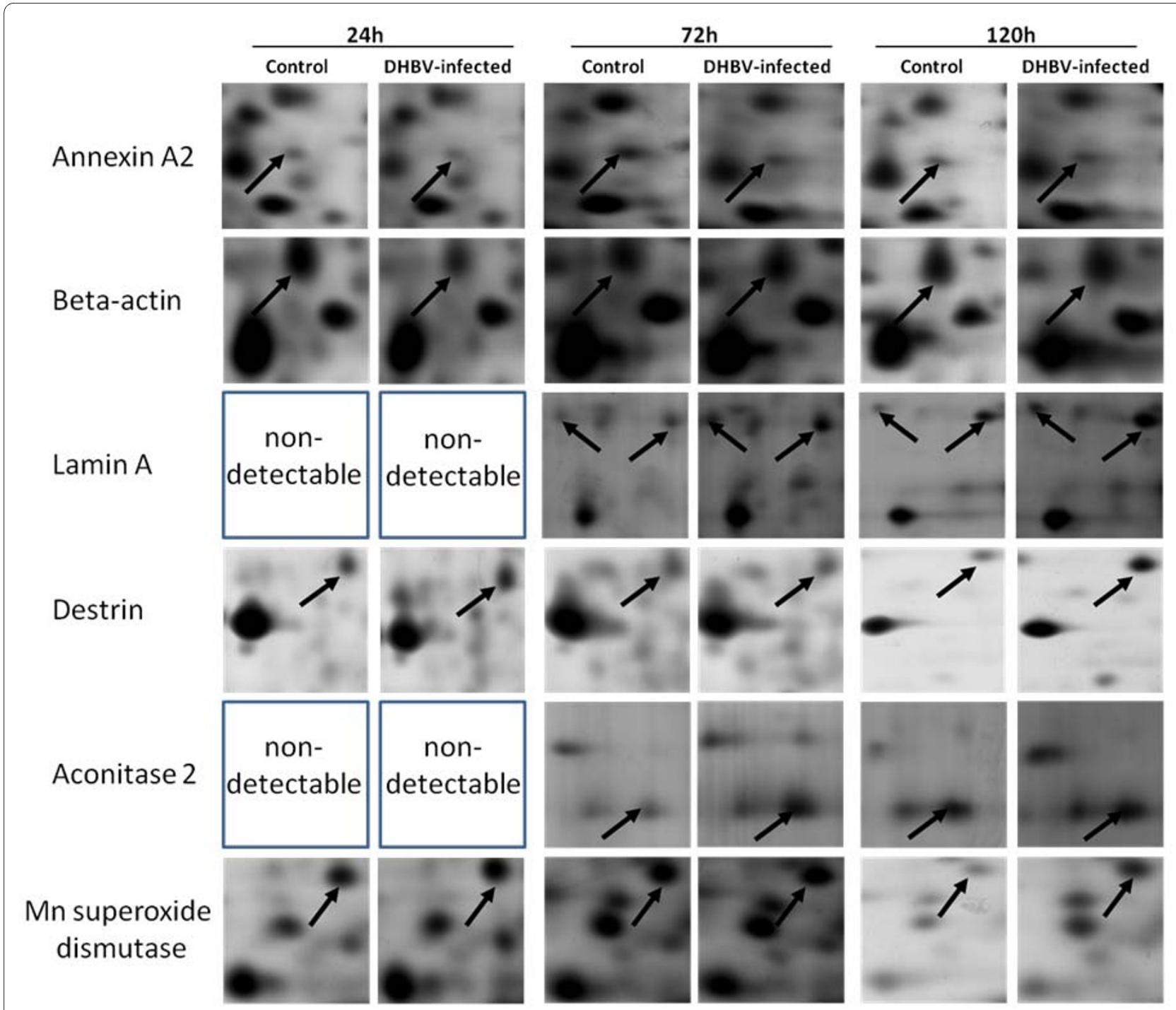

Figure 3 The enlarged 2-DE profiles of the differentially expressed proteins in the PDHs. The enlarged images of annexin A2, beta-actin, lamin A, destrin, Aconitase 2 and Mn superoxide dismutase protein spots are shown. Arrows indicate the differentially expressed proteins in 2-DE gels between DHBV infected and uninfected PDHs at 24, 72, and $120 \mathrm{~h}$ post-infection.

infection, including human immunodeficiency virus (HIV), adenovirus, Simian virus 40 , and vaccinia virus [31-34]. However, the actin cortex beneath the plasma membrane can also be an obstacle for virus entry or budding [35]. It has been reported that DHBV entry depends on both intact microtubules and their dynamic turnover but not actin cytoskeleton [28]. Therefore the role of actin in DHBV replication is required to further investigation.

Lamin A is key structural components of the nuclear lamina and lamins, involving in DNA replication and gene expression, as well as presenting a natural barrier against most DNA viruses such as human cytomegalovirus (HCMV), Kaposi's sarcoma-associated herpesvirus, herpes simplex virus (HSV) 1 and Epstein-Barr virus [36].
Lamin A/C is phosphorylated in HSV-infected cells supporting a role in regulating virus capsid nuclear egress $[37,38]$. Infection of Epstein-Barr virus induced disassembly of the nuclear lamina and redistribution of nuclear lamin for the nuclear egress [39]. The expression of lamin A with different isoforms, were up-regulated in DHBV infected PDHs, suggesting that lamin A may play a role in DHBV replication.

In DHBV infected PDHs, up-regulated expressions of amino acid metabolism enzymes, catalyzing interconversion of glutamate, histidine, and proline (Glutamate dehydrogenase 1, Urocanate hydratase, Delta-1-pyrroline-5-carboxylate dehydrogenase, the orthologs in human referred to protein 16, 19 and 20, 22 in Table 1), indicate that glutamine metabolism is enhanced. Switch- 


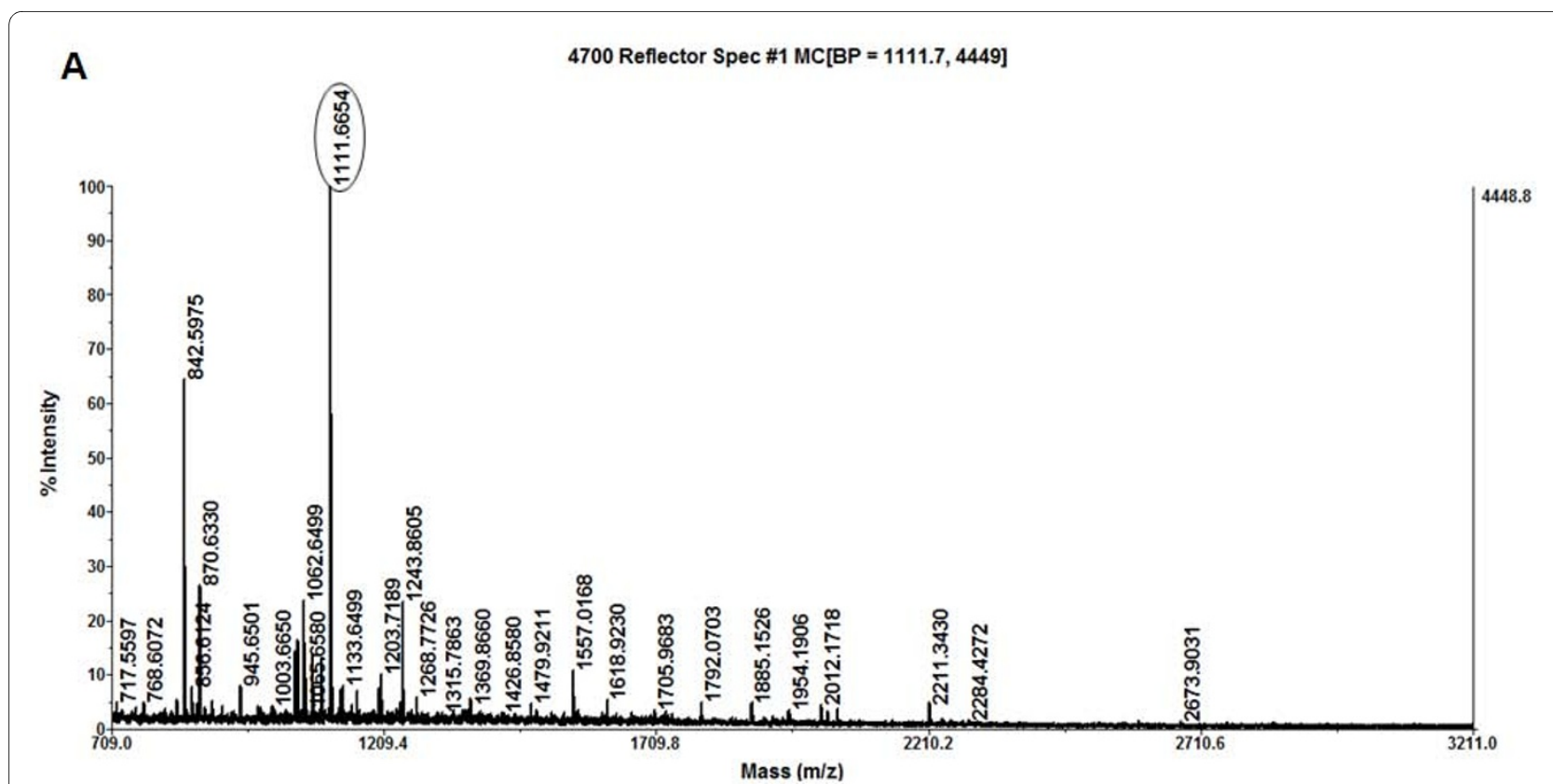

\section{B}

$4700 \mathrm{MS} / \mathrm{MS}$ Precursor $1111.67 \mathrm{Spec} \# 1 \mathrm{MC}[\mathrm{BP}=1110.9,2381]$

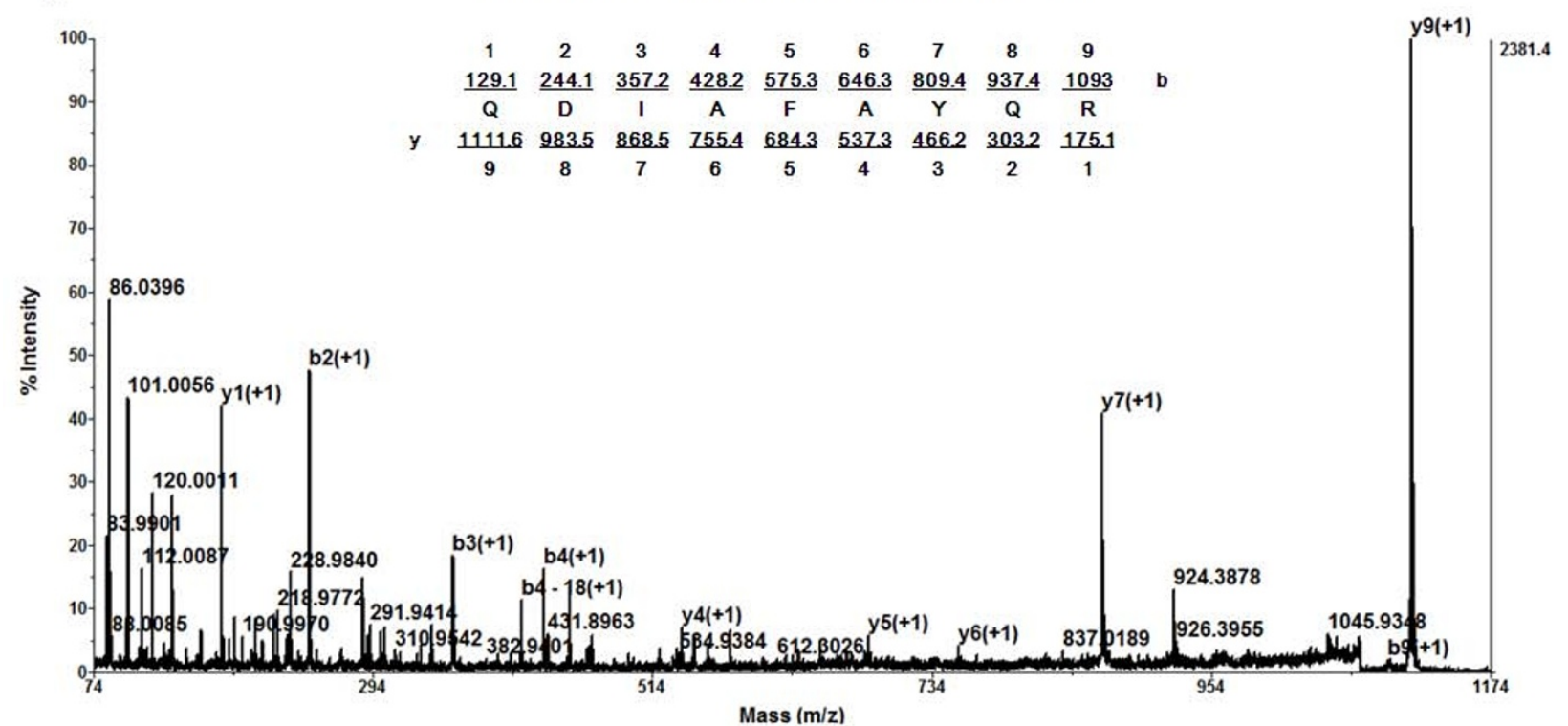

Figure 4 Representative mass spectra of annexin A2 analyzed by MALDI-TOF/TOF MS. The differentially expressed protein spot 49 was in-gel digested by trypsin, and peptide mixture was analyzed by MALDI-TOF/TOF Proteomics Analyzer. (A) MS spectrum with tryptic peptides of annexin A2, (B) MS/MS spectrum of the precursor ion with $\mathrm{m} / \mathrm{z} 1111.67$ marked in A for peptide QDIAFAYQR of annexin A2; fragments observed in the spectrum were underlined and assigned.

ing the anaplerotic substrate from glucose to glutamine to accommodate the biosynthetic and energetic needs of the viral infection and to allow glucose to be used biosynthetically was reported in HCMV infection [40]. HCVinfected cells exhibit increased levels of the enzymes catalyzing glutamine flux to replenish metabolic intermediates through the latter half of the citric acid cycle providing substrates for ATP production [18]. Thus simi- lar mechanism of glutamine metabolism may be at work in DHBV infection.

Stress response associated proteins including endoplasmic reticulum stress associated proteins such as Hsp70, and chaperonin containing t-complex polypeptide 1 (TCP1) and oxidative stress associated proteins such as antioxidant enzymes $\mathrm{Mn}$ superoxide dismutase and peroxiredoxin-3 (similar to antioxidant protein isoform 2) were found to be up-regulated post DHBV infection. 


$\begin{array}{llc}\text { Protein Name } & \text { Functions indicated in viral infections } & \text { References }\end{array}$

Aconitase 2, mitochondrial Binding to the 3'-untranslated region of the mouse hepatitis virus genome and increasing virus production as well as viral protein synthesis at early hours of infection

Phosphoglycerate kinase 1

Triosephosphate isomerase

Phosphoglycerate mutase 1

Alpha-enolase

GAPDH

$\operatorname{Lamin} \mathrm{A}$

Beta-actin

Dynein, light chain

Cofilin-2

Heat shock protein $70 \mathrm{~B}$

Annexin A2

Elongation factor 2

Ovotransferrin
Regulating Sendai virus transcription through their interactions with tubulin Increased between cancerous and noncancerous tissues from hepatocellular carcinoma patients

Specifically binding to the core region of HCV RNA genome in vitro

A candidate biomarker for HCV-related hepatocellular carcinoma; required for efficient transcription of Sendai virus genome

May interfere in the life-cycle of HBV to phosphorylate HBV core protein and playing roles in $\mathrm{HBV}$ infection in intracellular processes

Impeding HSV-1 infectivity; Phosphorylated in HSV-infected cells, regulating virus capsid nuclear egress; Epstein-Barr virus reactivation-mediated redistribution of nuclear lamin to modulate the cellular environment for virion production; cytomegalovirus induced distortion of the nuclear lamina

Actin rearrangements contribute to Simian virus 40 endocytosis; required by vira particle up-taking and infection establishment, including HIV, adenovirus, Simian virus 40 , and vaccinia virus, etc

Regulating Gag and viral RNA egress on endosomal membranes in the cytoplasm to directly impact on viral production; microtubule-dependent dynein activity increased through activation of the $\mathrm{p} 38 \mathrm{MAPK}$ by HBx, perhaps facilitating the process of maturation; directly used by poliovirus for retrograde axonal transport

Possible involving in the process of HIV initial binding and fusion steps, and inhibiting some subsequent early post-entry events in HIV infection of T cells HBV P protein activation in vitro is fundamentally dependent on $\mathrm{Hsc} 70 / \mathrm{Hsp} 40$; involving in $\mathrm{HBV}$ morphogenesis as a chaperone

Assisting in the assembly of HIV, and supporting HIV-1 infection as a cellular cofactor; enhancing cytomegalovirus binding and membrane fusion and plasminogen

Interacting with hepatitis B virus core protein in leukocytes; possessing a highly conserved anti-apoptotic activity induced by HIV-1 viral protein $\mathrm{R}$

Playing a crucial role in protecting the whole chicken embryo fibroblasts from Marek's disease virus infection spreading supporting the replication of influenza viruses by mediating activation of
Nanda et al., 2001. J Virol. 75, 3352-62.

Ogino et al., 2001. Biochem Biophys Res Commun. 285, 447-55. Kuramitsu et al., 2005. Expert Rev Proteomics. 2, 589-601.

Su et al., 2007. Intervirology. 50, 303-9.

Takashima et al., 2005. Proteomics. 5, 1686-92.

Ogino et al., 2001. Biochem Biophys Res Commun. 285, 447-55.

Duclos-Vallee et al., 1998. J Gen Virol. 79 (Pt 7), 1665-70.

Duclos-Vallee et al., 2002. Hepatol Res. 22, 65-73.

Mou et al., 2008. J Virol. 82, 8094-104.

Mou et al., 2007. J Virol. 81, 6459-70.

Lee et al, 2008. J Virol. 82, 11913-26.

Milbradt et al., 2007. J Gen Virol. 88, 2642-50.

Pelkmans et al., 2002. Science. 296, 535-9.

Pollard et al, 2003. Cell. 112, 453-65.

Bukrinskaya et al., 1998. J Exp Med. 188, 2113-25.

Li et al., 1998. J Virol. 72, 8806-12.

Ploubidou et al., 2001. Curr Opin Cell Biol. 13, 97-105.

Lehmann et al., 2009. J Biol Chem. 284, 14572-85.

Kim et al., 2007. J Virol. 81, 1714-26.

Gonzalez et al., 2007. Intervirology. 50, 214-8.

Liu et al., 2009. Sci Signal. 2, pe23.

Beck et al., 2003. J Biol Chem. 278, 36128-38. Prange et al., 1999. Biol Chem. 380, 305-14.

Ma et al., 2004. J Exp Med. 200, 1337-46.

Raynor et al., 1999. Biochemistry. 38, 5089-95. LeBouder et al., 2008. J Virol. 82, 6820-8.

Lin et al., 2006. World J Gastroenterol. 12, 1043-8. Zelivianski et al., 2006. Apoptosis. 11, 377-88.

Giansanti et al., 2007. Biochem Cell Biol. 85, 150-5. 


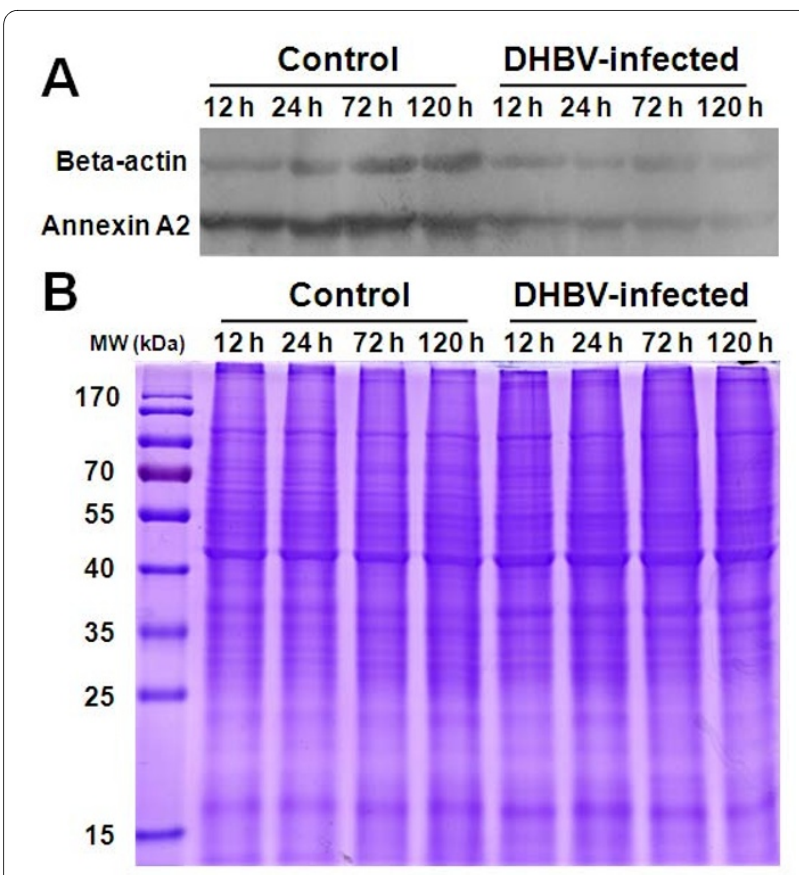

Figure 5 Confirmation of the differentially expressed proteins of annexin $\mathrm{A} 2$ and beta-actin by Western blot. The equal cell lysates of control and DHBV infected PDHs at 12,24,72 and $120 \mathrm{~h}$ post-infection were separated by SDS-PAGE, and detected by Western blotting with mouse anti-beta-actin and anti-duck annexin A2 as primary antibodies and then followed by horseradish peroxidase-conjugated goat antimouse $\lg G$ as secondary antibody (A). The same amount protein of each sample were applied to a parallel SDS-PAGE gel and stained with Coomassie brilliant blue (B)

Hsp70 assists folding of many newly synthesized polypeptides, and refolding of the proteins misfolded [41,42]. Hsp70 can enhance flock house virus replication [43,44]. Hsp70 and Hsp90 participate in dengue virus entry as a receptor complex [45]. Moreover, HBV P protein activation in vitro is fundamentally dependent on heat shock protein 70 family Hsc70/Hsp40 [46]. In HBV-replicating HepAD38 cell, expressions of heat shock proteins (Hsp70 and Hsp90) and Mn superoxide dismutase increase, after HBV replication induced by tetracycline [47]. In humanized transgenic mice, inhibition of HBV replication results in suppression of $\mathrm{Mn}$ superoxide dismutase expression in hepatocytes $[47,48]$. It suggests that oxidative stress can be induced by hepadnavirus replication as Epstein-Barr virus [49].

Annexin A2, belongs to a family of calcium-dependent, phospholipid binding proteins, is involved in many biological processes, such as the $\mathrm{Ca}^{2+}$ dependent exocytosis, calcium transport and cell proliferation. It participates in viral infection, including assisting in the assembly of HIV in monocyte-derived macrophages [50], as a cellular cofactor supporting HIV-1 infection [51], enhancing cytomegalovirus binding and membrane fusion [52] and supporting the replication of influenza viruses by mediating activation of plasminogen [53]. It has been reported that $\mathrm{HBV}$ polymerase activity was inhibited by interacted with S100A10, a protein binding to annexin A2 [54]. In HepG2.2.15 compared with HepG2, annexin A2 was revealed down-regulated [55], which was consistent with our observation in DHBV-PDHs model and confirmed by Western blot analysis. It indicated that annexin A2 may involve in hepadnavirus infection and warrants further investigation.

Beta-actin and GAPDH are usually referred as the internal standards for detections of RNA transcription and protein expression of genes. However, those proteins were found to be down-regulated post DHBV infection by 2-DE analysis. Recently, accumulated evidence showed that in HBV-related hepatocellular carcinoma or viral infections, beta-actin and GAPDH are unsuitable controls in quantitative mRNA expression or Western blot analysis due to variations in expression [56-60], though there are controversial observations [61]. These findings therefore highlight the importance of re-evaluating the housekeeping genes whose expressions may be affected by hepadnavirus infection.

\section{Conclusions}

In summary, the present study explored global changes in cellular protein expression of hepadnavirus infection by 2-DE analysis, using a natural DHBV-PDHs infection system. Forty-two differentially expressed proteins in DHBV infected PDHs have been identified by MS/MS. Most of them involve in carbohydrate metabolism, amino acid metabolism, stress responses and cytoskeleton processes including alpha-enolase, beta-actin, lamin A and annexin A2. It suggests that those proteins may play important roles in hepadnavirus infection. Differential expressions of annexin A2 and beta-actin were confirmed by Western blot analysis. Further investigation of the roles of the differentially expressed cellular proteins will help to understand cellular and molecular mechanisms of hepadnavirus infection.

\section{Materials and methods PDHs culture}

Cherry Valley ducks (Anas platyrhynchos) were purchased from Breeding Center of Shanghai Institute of Veterinary Medical Sciences, China. Animal protocols were approved by the Ethics Committee of Fudan University. Three-day-old ducklings with no congenital DHBV infection detected by PCR (sence: 5'-CTCACTTTGTGGATCTCATTG-3', antisense: 5'-ATCGGATAGTCGGGTTGG-3'), were used for PDHs cultures. Duck hepatocytes were isolated with in situ liver perfusion method with modifications. After the duck was anesthetized with approximately $0.3 \mathrm{ml}$ of $0.75 \%$ pentobarbital 
sodium, the liver was perfused via portal vein with prewarmed liver perfusion medium (Gibco Laboratories), then the inferior vena cava was cut to effuse the buffer liquid when the liver was engorged. At first, perfusion was maintained at 15 to $20 \mathrm{ml}$ per minute with $100 \mathrm{ml}$ of liver perfusion medium until the liver became blanch, then the liver became soft followed by $50 \mathrm{ml}$ digestion buffer with $1 \mu \mathrm{g} / \mathrm{ml}$ of collagenase type IV (Sigma) in L15 medium (Gibco). After the perfusion, the gallbladder was removed and hepatocytes were dispersed in L-15 medium. Hepatocytes were filtered through sterilized gauze, centrifuged at $40 \mathrm{~g}$ for $4 \mathrm{~min}$, and washed three times with Hepatocyte Wash Medium (Gibco). Then $4 \times$ $10^{6}$ hepatocytes were seeded onto 100 -mm-diameter dish and incubated in L-15 medium containing 5\% FBS (Gibco Laboratories), $15 \mathrm{mM}$ HEPES, $100 \mathrm{U}$ penicillin per liter, $100 \mathrm{mg}$ of streptomycin per liter, $1 \mathrm{mg}$ of insulin (Sigma) per liter and $10^{-5} \mathrm{M}$ hydrocortisone-hemisuccinate (Sigma) at $37^{\circ} \mathrm{C}$. The medium was changed every day.

\section{DHBV infection of PDHs}

Infectious DHBV were produced by LMH-D2 cell line which carries a stably integrated DHBV dimer and constitutively secretes DHBV virions (generous gift of William Mason, Fox Chase Cancer Center, USA) [62]. DHBV particles were obtained from LMH-D2 cells by ultracentrifugation, and the virus pellet was suspended in PBS with $10 \%$ glycerol. DHBV was quantified using real time PCR as a titer of $2 \times 10^{9}$ copies per milliliter. PDHs cultured $16 \mathrm{~h}$ after plating were infected with purified DHBV viral particles at MOI of 30 , and incubated at $37^{\circ} \mathrm{C}$ overnight. Then, they were washed with PBS three times and cultured for 12, 24, 72 and $120 \mathrm{~h}$ in L15 medium supplemented with $5 \%$ FBS.

\section{Detection of DHBV infected PDHs}

The efficiency of DHBV infection in PDHs was determined by indirect immunofluorescence and Southern blot hybridization. Monolayers of PDHs grown on glass coverslips were fixed directly by adding $4 \%$ polyoxymethylene at room temperature for $20 \mathrm{~min}$, washed twice with PBS and preincubated with $3 \%$ bovine serum albumin for $30 \mathrm{~min}$. After incubation with a 1:100 dilution of monoclonal mouse anti-DHBV preS (generous gift of John C. Pugh and William Mason, Fox Chase Cancer Center, USA) at $37^{\circ} \mathrm{C}$ for $60 \mathrm{~min}$, the cells were washed three times with PBS, subsequently incubated with a 1:200 dilution of FITC-conjugated sheep anti-mouse IgG (GGHL-90F, Immunology Consultants Laboratory) at $37^{\circ} \mathrm{C}$ for $30 \mathrm{~min}$. Cell nucleus were stained with $1 \mu \mathrm{g} / \mathrm{ml}$ 4',6'-diamidino-2-phenylindole (DAPI, Sigma) and mounted in $50 \%$ glycerol in PBS. Efficiency of DHBV infection was observed by the confocal laser scanning microscope (Leica). To detect DHBV replication, intrac- ellular DNA was extracted from DHBV infected or uninfected PDHs. Forty micrograms of DNA from each sample was separated on a 1.5\% agarose gel, and analyzed by Southern blot hybridization with an alpha-32P-dCTP labeled DHBV-specific probe for detection as described previously [63].

\section{PDHs' protein sample preparation for 2-DE}

The DHBV-infected and control (uninfected) PDHs at 24, 72 , and $120 \mathrm{~h}$ post-infection were washed three times with ice-cold PBS before harvesting and stored at $-80^{\circ} \mathrm{C}$. PDHs for DHBV infection or the uninfected controls were from the same duck in order to avoid individual differences. Approximately $2 \times 10^{7}$ cells were lysed in $1 \mathrm{ml}$ lysis buffer (7 M urea, $2 \mathrm{M}$ Thiourea, 2\% (w/v) CHAPS, $50 \mathrm{mM}$ dithiothreitol (DTT), 2\% (v/v) pH 3-10 nonlinear immobilized $\mathrm{pH}$ gradient (IPG) buffer (Amersham Biosciences) containing $1 \%$ protease inhibitor cocktail (Roche) and $1 \mathrm{mM}$ PMSF (Sigma)), then sonicated on ice for 12 cycles, each consisting of $5 \mathrm{~s}$ pulse and $10 \mathrm{~s}$ pause. After centrifugation at $20,000 \mathrm{~g}$ at $4^{\circ} \mathrm{C}$ for $1 \mathrm{~h}$, the supernatants of lysates were divided into aliquots and the protein concentrations were determined by the Bradford assay. Then, aliquots were stored at $-80^{\circ} \mathrm{C}$ for further analysis.

\section{Two-dimensional gel electrophoresis and image analysis}

The 2-DE gels were performed using 24-cm IPG strips (pH 3-10, nonlinear, GE Healthcare) in Ettan IPGphor Isoelectric Focusing System (Amersham Biosciences) plus Ettan-Dalt six system (Amersham Biosciences) according to the manufacturer's instructions. To compensate the variability of gel electrophoresis, at least three replicate gels were performed for each group. In the first dimensional isoelectric focusing (IEF), $120 \mu \mathrm{g}$ proteins of each sample were diluted to $450 \mu \mathrm{l}$ with rehydration buffer containing $8 \mathrm{M}$ urea, $2 \%$ (w/v) CHAPS, $50 \mathrm{mM}$ DTT, $0.5 \%(\mathrm{v} / \mathrm{v})$ ampholyte $(\mathrm{pH} 3-10$, nonlinear, Amersham Biosciences), and IPG strips were allowed to rehydrate in the above solution under mineral oil. IEF was performed as follow: $30 \mathrm{~V}$ for $6 \mathrm{~h}$ (active rehydration); $60 \mathrm{~V}$ for $6 \mathrm{~h}$ (active rehydration); $500 \mathrm{~V}$ for $2 \mathrm{~h}$, rapid; $1,000 \mathrm{~V}$ for $2 \mathrm{~h}$, rapid; 4,000 V for $2 \mathrm{~h}$, linear; linear ramping to $8,000 \mathrm{~V}$ for $2 \mathrm{~h}$, and finally $8,000 \mathrm{~V}$ for about $7 \mathrm{~h}$ with a total of 64 $\mathrm{KVh}$ at $20^{\circ} \mathrm{C}$. Then the IPG strips were incubated in equilibration buffer (75 mM Tris- $\mathrm{HCl}(\mathrm{pH} 8.8), 6 \mathrm{M}$ urea, $29.3 \%(\mathrm{v} / \mathrm{v})$ glycerol, $2 \%(\mathrm{w} / \mathrm{v})$ SDS and $0.002 \%(\mathrm{w} / \mathrm{v})$ bromophenol blue) containing 2\% (w/v) DTT for $15 \mathrm{~min}$ with gentle agitation, followed by incubation in the same equilibration buffer supplemented with $2.5 \%(\mathrm{w} / \mathrm{v})$ iodoacetamide for $15 \mathrm{~min}$ at room temperature. The second dimension SDS-PAGE was performed on $1 \mathrm{~mm}$ thick $12.5 \%$ polyacrilamide vertical gels in Ettan-Dalt Six system using $5 \mathrm{~W} /$ gel for $30 \mathrm{~min}$, and followed by $12 \mathrm{~W} /$ gel 
at $10^{\circ} \mathrm{C}$ until the bromophenol blue dye front reached the end of the gels. The gels were stained by a modified silver staining method compatible with MS analysis [64] and scanned at $300 \mathrm{dpi}$ (dots/inch) using ImageScanner (UMAX, Amersham Biosciences).

Images were captured and analyzed by ImageMaster 2D platinum 6.0 software (Amersham Biosciences). The percentage of the volume of the spots representing a certain protein was determined in comparison with the total proteins present in the 2-DE gel. To select differentially expressed protein spots, quantitative analysis was performed using the Student's $t$-test to compare the percentage volumes of spots between DHBV infected and uninfected groups at three time points. The differentially expressed protein spots with $p$-values less than 0.05 were considered as significant differences, and at least 1.5 fold difference in percentage of the volume for each spot was set as a threshold. These protein spots were selected and subjected to in-gel tryptic digestion and identification by MS.

\section{In-gel tryptic digestion}

The differentially expressed protein spots were manually excised from the sliver-stained gels (each gel of $120 \mu \mathrm{g}$ protein) and placed into a 96-well microplate. The gel pieces were destained with a solution of $15 \mathrm{mM}$ potassium ferricyanide and $50 \mathrm{mM}$ sodium thiosulfate (1:1) at room temperature for $10 \mathrm{~min}$, then washed twice with deionized water, each for $30 \mathrm{~min}$, and dehydrated in $80 \mu \mathrm{l}$ of acetonitrile (ACN) twice. Then the samples were swollen in a digestion buffer containing $25 \mathrm{mM} \mathrm{NH}_{4} \mathrm{HCO}_{3}$ and $12.5 \mathrm{ng} / \mu \mathrm{l}$ trypsin (Promega) at $4^{\circ} \mathrm{C}$ after $30 \mathrm{~min}$ incubation, and incubated at $37^{\circ} \mathrm{C}$ for more than $12 \mathrm{~h}$. The peptide mixtures from the gel were extracted twice using $0.1 \%$ trifluoroacetic $/ 50 \% \mathrm{ACN}$ at room temperature, re-suspended with $0.7 \mu \mathrm{l}$ matrix solution ( $\alpha$-cyano4-hydroxy-cinnamic acid (Sigma) in $0.1 \%$ trifluoroacetic, $50 \% \mathrm{ACN}$ ), allowed to dry in air under the protection of N2.

\section{Mass spectrometric analysis and database searching}

The peptide mixtures from samples were analyzed by 4700 MALDI-TOF/TOF Proteomics Analyzer (Applied Biosystems). The UV laser was operated at a $200 \mathrm{~Hz}$ repetition rate with wavelength of $355 \mathrm{~nm}$. The accelerated voltage was operated at $20 \mathrm{kV}$. Myoglobin digested by trypsin was used to calibrate the mass instrument with internal calibration mode. All acquired spectra of samples were processed using 4700 series Explore software (Applied Biosystems) in a default mode. The parent mass peaks with mass range 700-3200 Da and minimum S/N 20 were picked out for tandem TOF/TOF analysis. Combined MS and MS/MS spectra were submitted to MASCOT (V2.1, Matrix Science) by GPS Explorer software
(V3.6, Applied Biosystems) and searched with the following parameters: NCBInr database (release date: 2009.11), taxonomy of bony vertebrates or viruses, trypsin digest with one missing cleavage, none fixed modifications, MS tolerance of $100 \mathrm{ppm}, \mathrm{MS} / \mathrm{MS}$ tolerance of $0.6 \mathrm{Da}$ and possible oxidation of methionine. Known contaminant ions (human keratin and tryptic autodigest peptides, etc.) were excluded. MASCOT protein scores (based on MS and MS/MS spectra) with greater than 72 were considered statistically significant $(p<0.05)$. The individual MS/MS spectrum with statistically significant (confidence interval >95\%) and best ion score (based on MS/ MS spectra) was accepted. To eliminate the redundancy of proteins that appeared in the database under different names and accession numbers, the protein belonging to the species Anas platyrhynchos or with the highest protein score (top rank) was singled out.

\section{Preparation of polyclonal mouse anti-annexin A2}

Duck cDNA of annexin A2 was amplified by reverse transcription-PCR with the primers designed according to the sequence of the chicken annexin A2 (GenBank Accession No. gi|45382533, sense: 5'-CCGCTCGAGGTCCTCTCCACCACACAGGT-3' and antisense: 5'-CCG CTCGAGGTCCTCTCCACCACACAGGT-3'). The fulllength of duck annexin A2 amplified from PDHs, was cloned into prokaryotic expression plasmid pET-28a (Novagen). Recombinant annexin A2 with C-terminal fusion His-tag was induced by IPTG, and purified by NiNTA affinity chromatography (QIAGEN). BALB/c mice were immunized by the purified recombinant duck annexin A2 with Freund's complete adjuvant (Sigma). The serum was collected 2 weeks following the final injection and the levels of anti-duck-annexin A2 antibody titers from immunized mice were determined by Western blot.

\section{Western blot analysis of differential proteins}

Differential expression of duck beta-actin, annexin A2, Hsp70, destrin and lamin A were confirmed by Western blot analysis. The primary antibodies for detection were as follow: a monoclonal antibody against beta-actin (Sigma), rabbit anti-human lamin A polyclonal antibody (Santa Cruz Biotechnology and Proteintech), rabbit antihuman Hsp70 polyclonal antibody (Santa Cruz Biotechnology), rabbit Hsp70 polyclonal antibody (BIOS), rabbit anti-human destrin polyclonal antibody (PROTEINTECK) and mouse anti-duck-annexin A2 polyclonal antibody prepared in our laboratory described as above. Thirty microgram proteins from each sample were separated in 12\% SDS-PAGE gels and transferred to PVDF membranes using the transfer system (BioRad). The blots were blocked with $5 \%$ nonfat milk for $2 \mathrm{~h}$ at room temperature and incubated at $4^{\circ} \mathrm{C}$ overnight with 1:200-1:500 
dilution of primary antibody. The blots were then washed four times with PBS containing $0.1 \%$ Tween-20, and incubated with the appropriate horseradish peroxidase-conjugated secondary antibody (Santa Cruz Biotechnology) 1 hour at room temperature. After washed four times with PBS containing $0.1 \%$ Tween-20, the bands were developed with ECL detection reagent (Pierce). The same amount protein of each sample was applied to a parallel SDS-PAGE gel and stained with Coomassie brilliant blue.

\section{List of abbreviations}

2-DE: two-dimensional polyacrylamide gel electrophoresis; ACN: acetonitrile; DHBV: Duck hepatitis B virus; DAPI: 4',6'-diamidino-2-phenylindole; DTT: dithiothreitol; FBS: fetal bovine serum; GAPDH: glyceraldehyde-3phosphate dehydrogenase; $\mathrm{HBV}$ : hepatitis B virus; $\mathrm{HCV}$ : hepatitis $C$ virus; HCMV: human cytomegalovirus; HIV: human immunodeficiency virus; Hsp: heat shock protein; HSV: herpes simplex virus; IEF: isoelectric focusing; IPG: immobilized $\mathrm{pH}$ gradient; MOI: multiplicity of infection; MS: mass spectrometry; MS/MS: tandem mass spectrometry, PBS: phosphate-buffered saline; PCR: polymerase chain reaction; PDHs: Primary duck hepatocytes; TCP1: t-complex polypeptide 1; WHBV: Woodchuck hepatitis B virus.

\section{Additional material}

\section{Additional File 1 Detection of DHBV replicative intermediates in}

PDHs. DHBV DNA in PDHs was detected by Southern blot hybridization with an alpha-32P-dCTP labeled DHBV-specific probe.

Additional File 2 Detection of DHBV DNA in the supernatant of PDHs. Viral genomes in the supernatant of DHBV infected PDHs were quantified by real time PCR

Additional File 3 The numbers of differentially expressed protein spots detected by 2-DE. The numbers of differentially expressed protein spots revealed by 2-DE at 24, 72, $120 \mathrm{~h}$ post-DHBV infection were listed. Additional File 4 Differentially expressed protein spots in DHBVinfected PDHs not identified by MALDI-TOF/TOF. The expression ratio between DHBV infected and uninfected PDHs of unidentified spots underlined in Figure 2 were listed.

Additional File 5 Peptides of differentially expressed proteins in DHBV-infected PDHs identified by MALDI-TOF/TOF. Peptides count and peptides identified were listed.

Competing interests

The authors declare that they have no competing interests.

\section{Authors' contributions}

DO was responsible for the conception and design of the study, $Y Z$ were responsible for $\mathrm{PDH}$ s culture, virus infection and sample preparation. $\mathrm{HB}$ and SQ carried out the 2-DE gels experiments, image analysis and excised the protein spots. $X Z$ performed the mass spectrometric analyses. $Y Z$ and LY confirmed the differential expression by Western blot. $Y Z$ and HB carried out the analysis and interpretation of data. $D Q, Y Z$ and $H B$ wrote the manuscript. BX, $\mathrm{SZ}, \mathrm{QL}, \mathrm{RY}, \mathrm{TZ}, \mathrm{PY}$ have been involved in drafting the manuscript or revising it critically for important content. All authors read and approved the final manuscript.

\section{Acknowledgements}

We would like to thank Professor Alastair I. H. Murchie for careful reading and correcting the English of the revised manuscript. This work was supported by National Natural Science Foundation of China (30670092, J0730860) and the Program of Ministry of Science and Technology of China (2010DFA32100 2008ZX10004-014, 2008ZX10002-002 and 2008ZX10002-011).

\section{Author Details}

${ }^{1}$ Key Laboratory of Medical Molecular Virology of Ministries of Education and Health, Institute of Medical Microbiology and Institutes of Biomedical Sciences, Shanghai Medical College of Fudan University, Shanghai, China and 2Department of Chemistry, Institutes of Biomedical Sciences, Fudan University, Shanghai, China

Received: 12 February 2010 Accepted: 7 June 2010

Published: 7 June 2010

\section{References}

1. Chisari FV, Ferrari C: Hepatitis B virus immunopathogenesis. Annu Rev Immunol 1995, 13:29-60

2. Ganem D, Prince AM: Hepatitis B virus infection--natural history and clinical consequences. N Engl J Med 2004, 350:1118-1129.

3. Galle PR, Hagelstein J, Kommerell B, Volkmann M, Schranz P, Zentgraf H: In vitro experimental infection of primary human hepatocytes with hepatitis B virus. Gastroenterology 1994, 106:664-673.

4. Gripon P, Rumin S, Urban S, Le Seyec J, Glaise D, Cannie I, Guyomard C, Lucas J, Trepo C, Guguen-Guillouzo C: Infection of a human hepatoma cell line by hepatitis B virus. Proc Natl Acad Sci USA 2002, 99:15655-15660

5. Lucifora J, Durantel D, Belloni L, Barraud L, Villet S, Vincent IE, MargeridonThermet S, Hantz O, Kay A, Levrero M, Zoulim F: Initiation of hepatitis B virus genome replication and production of infectious virus following delivery in HepG2 cells by novel recombinant baculovirus vector. $J$ Gen Virol 2008, 89:1819-1828.

6. Hantz O, Parent R, Durantel D, Gripon P, Guguen-Guillouzo C, Zoulim F: Persistence of the hepatitis B virus covalently closed circular DNA in HepaRG human hepatocyte-like cells. J Gen Virol 2009, 90:127-135.

7. Zhang YY, Theele DP, Summers J: Age-related differences in amplification of covalently closed circular DNA at early times after duck hepatitis B virus infection of ducks. J Virol 2005, 79:9896-9903.

8. Crettaz J, Otano I, Ochoa L, Benito A, Paneda A, Aurrekoetxea I, Berraondo P, Rodriguez-Madoz JR, Astudillo A, Kreppel F, et al:: Treatment of chronic viral hepatitis in woodchucks by prolonged intrahepatic expression of interleukin-12. J Virol 2009, 83:2663-2674

9. Ventelon-Debout M, Delalande F, Brizard JP, Diemer $H$, Van DA, Brugidou C: Proteome analysis of cultivar-specific deregulations of Oryza sativa indica and $O$. sativa japonica cellular suspensions undergoing rice yellow mottle virus infection. Proteomics 2004, 4:216-225.

10. Schlee M, Krug T, Gires O, Zeidler R, Hammerschmidt W, Mailhammer R, Laux G, Sauer G, Lovric J, Bornkamm GW: Identification of Epstein-Barr virus (EBV) nuclear antigen 2 (EBNA2) target proteins by proteome analysis: activation of EBNA2 in conditionally immortalized B cells reflects early events after infection of primary $B$ cells by EBV. J Virol 2004, 78:3941-3952.

11. Casado-Vela J, Selles S, Martinez RB: Proteomic analysis of tobacco mosaic virus-infected tomato (Lycopersicon esculentum M.) fruits and detection of viral coat protein. Proteomics 2006:S196-S206.

12. Alfonso P, Rivera J, Hernaez B, Alonso C, Escribano JM: Identification of cellular proteins modified in response to African swine fever virus infection by proteomics. Proteomics 2004, 4:2037-2046.

13. Tong A, Wu L, Lin Q, Lau QC, Zhao X, Li J, Chen P, Chen L, Tang H, Huang C, Wei YQ: Proteomic analysis of cellular protein alterations using a hepatitis B virus-producing cellular model. Proteomics 2008 8:2012-2023.

14. Narayan R, Gangadharan B, Hantz O, Antrobus R, Garcia A, Dwek RA Zitzmann N: Proteomic analysis of HepaRG cells: a novel cell line that supports hepatitis B virus infection. J Proteome Res 2009, 8:118-122.

15. Zhao C, Fang CY, Tian XC, Wang L, Yang PY, Wen YM: Proteomic analysis of hepatitis $B$ surface antigen positive transgenic mouse liver and decrease of cyclophilin A. J Med Virol 2007, 79:1478-1484. 
16. Schultz U, Grgacic E, Nassal M: Duck hepatitis B virus: an invaluable model system for HBV infection. Adv Virus Res 2004, 63:1-70.

17. Pugh JC, Summers JW: Infection and uptake of duck hepatitis B virus by duck hepatocytes maintained in the presence of dimethyl sulfoxide. Virology 1989, 172:564-572.

18. Diamond DL, Syder AJ, Jacobs JM, Sorensen CM, Walters KA, Proll SC, McDermott JE, Gritsenko MA, Zhang Q, Zhao R, et al.: Temporal proteome and lipidome profiles reveal hepatitis $C$ virus-associated reprogramming of hepatocellular metabolism and bioenergetics. PLOS Pathog 2010, 6:e1000719.

19. Djavani M, Crasta OR, Zhang Y, Zapata JC, Sobral B, Lechner MG, Bryant J, Davis $H$, Salvato MS: Gene expression in primate liver during viral hemorrhagic fever. Virol J 2009, 6:20.

20. Shaw ML, Stone KL, Colangelo CM, Gulcicek EE, Palese P: Cellular proteins in influenza virus particles. PLOS Pathog 2008, 4:e1000085.

21. Denard J, Rundwasser S, Laroudie N, Gonnet F, Naldini L, Radrizzani M, Galy A, Merten OW, Danos O, Svinartchouk F: Quantitative proteomic analysis of lentiviral vectors using 2-DE. Proteomics 2009, 9:3666-3676.

22. Zang WQ, Fieno AM, Grant RA, Yen TS: Identification of glyceraldehyde3-phosphate dehydrogenase as a cellular protein that binds to the hepatitis B virus posttranscriptional regulatory element. Virology 1998 , 248:46-52.

23. Duclos-Vallee JC, Capel F, Mabit H, Petit MA: Phosphorylation of the hepatitis B virus core protein by glyceraldehyde-3-phosphate dehydrogenase protein kinase activity. J Gen Virol 1998, 79(Pt 7):1665-1670.

24. Duclos-Vallee JC, Capel F, Mabit H, Petit MA: Protein kinase and NOstimulated ADP-ribosyltransferase activities associated with glyceraldehyde-3-phosphate dehydrogenase isolated from human liver. Hepatol Res 2002, 22:65-73.

25. Pastorino B, Boucomont-Chapeaublanc E, Peyrefitte CN, Belghazi M, Fusai $\mathrm{T}$, Rogier C, Tolou HJ, Almeras L: Identification of cellular proteome modifications in response to West Nile virus infection. Mol Cell Proteomics 2009, 8:1623-1637.

26. Zheng X, Hong L, Shi L, Guo J, Sun Z, Zhou J: Proteomics analysis of host cells infected with infectious bursal disease virus. Mol Cell Proteomics 2008, 7:612-625

27. Jiang XS, Tang LY, Dai J, Zhou H, Li SJ, Xia QC, Wu JR, Zeng R: Quantitative analysis of severe acute respiratory syndrome (SARS)-associated coronavirus-infected cells using proteomic approaches: implications for cellular responses to virus infection. Mol Cell Proteomics 2005, 4:902-913.

28. Funk A, Mhamdi M, Lin L, Will H, Sirma H: Itinerary of hepatitis b viruses: delineation of restriction points critical for infectious entry. J Virol 2004, 78:8289-8300

29. Miralles F, Visa N: Actin in transcription and transcription regulation. Curr Opin Cell Biol 2006, 18:261-266.

30. Cudmore S, Cossart P, Griffiths G, Way M: Actin-based motility of vaccinia virus. Nature 1995, 378:636-638.

31. Pelkmans L, Puntener D, Helenius A: Local actin polymerization and dynamin recruitment in SV40-induced internalization of caveolae. Science 2002, 296:535-539.

32. Pollard TD, Borisy GG: Cellular motility driven by assembly and disassembly of actin filaments. Cell 2003, 112:453-465.

33. Li E, Stupack D, Bokoch GM, Nemerow GR: Adenovirus endocytosis requires actin cytoskeleton reorganization mediated by Rho family GTPases. J Virol 1998, 72:8806-8812.

34. Bukrinskaya A, Brichacek B, Mann A, Stevenson M: Establishment of a functional human immunodeficiency virus type 1 (HIV-1) reverse transcription complex involves the cytoskeleton. J Exp Med 1998, 188:2113-2125.

35. Marsh M, Bron R: SFV infection in CHO cells: cell-type specific restrictions to productive virus entry at the cell surface. J Cell Sci 1997 110(Pt 1):95-103.

36. Lee CP, Chen MR: Escape of herpesviruses from the nucleus. Rev Med Virol 2010:9999.

37. Mou F, Forest T, Baines JD: US3 of herpes simplex virus type 1 encodes a promiscuous protein kinase that phosphorylates and alters localization of lamin A/C in infected cells. J Virol 2007, 81:6459-6470.

38. Mou F, Wills EG, Park R, Baines JD: Effects of lamin A/C, lamin B1, and viral US3 kinase activity on viral infectivity, virion egress, and the targeting of herpes simplex virus $\mathrm{U}(\mathrm{L}) 34$-encoded protein to the inner nuclear membrane. J Virol 2008, 82:8094-8104.

39. Lee CP, Huang YH, Lin SF, Chang Y, Chang YH, Takada K, Chen MR: Epstein-Barr virus BGLF4 kinase induces disassembly of the nuclear lamina to facilitate virion production. J Virol 2008, 82:11913-11926.

40. Chambers JW, Maguire TG, Alwine JC: Glutamine metabolism is essential for human cytomegalovirus infection. J Virol 2010, 84:1867-1873.

41. Hartl FU, Hayer-Hartl M: Molecular chaperones in the cytosol: from nascent chain to folded protein. Science 2002, 295:1852-1858.

42. Mayer MP, Bukau B: Hsp70 chaperones: cellular functions and molecular mechanism. Cell Mol Life Sci 2005, 62:670-684

43. Serva S, Nagy PD: Proteomics analysis of the tombusvirus replicase: Hsp70 molecular chaperone is associated with the replicase and enhances viral RNA replication. J Virol 2006, 80:2162-2169.

44. Kampmueller KM, Miller DJ: The cellular chaperone heat shock protein 90 facilitates Flock House virus RNA replication in Drosophila cells. J Virol 2005, 79:6827-6837

45. Reyes-Del VJ, Chavez-Salinas S, Medina F, Del AR: Heat shock protein 90 and heat shock protein 70 are components of dengue virus receptor complex in human cells. J Virol 2005, 79:4557-4567.

46. Beck J, Nassal M: Efficient Hsp90-independent in vitro activation by $\mathrm{Hsc} 70$ and $\mathrm{Hsp} 40$ of duck hepatitis B virus reverse transcriptase, an assumed Hsp90 client protein. J Biol Chem 2003, 278:36128-36138.

47. Severi T, Ying C, Vermeesch JR, Cassiman D, Cnops L, Verslype C, Fevery J, Arckens L, Neyts J, van Pelt JF: Hepatitis B virus replication causes oxidative stress in HepAD38 liver cells. Mol Cell Biochem 2006 , 290:79-85.

48. Yao D, Li H, Gou Y, Zhang H, Vlessidis AG, Zhou H, Evmiridis NP, Liu Z: Betulinic acid-mediated inhibitory effect on hepatitis $B$ virus by suppression of manganese superoxide dismutase expression. FEBS J 2009, 276:2599-2614.

49. Lassoued S, Ben AR, Ayadi W, Gargouri B, Ben MR, Attia H: Epstein-Barr virus induces an oxidative stress during the early stages of infection in B lymphocytes, epithelial, and lymphoblastoid cell lines. Mol Cell Biochem 2008, 313:179-186.

50. Ryzhova EV, Vos RM, Albright AV, Harrist AV, Harvey T, Gonzalez-Scarano F: Annexin 2: a novel human immunodeficiency virus type $1 \mathrm{Gag}$ binding protein involved in replication in monocyte-derived macrophages. J Virol 2006, 80:2694-2704

51. Ma G, Greenwell-Wild T, Lei K, Jin W, Swisher J, Hardegen N, Wild CT, Wahl SM: Secretory leukocyte protease inhibitor binds to annexin II, a cofactor for macrophage HIV-1 infection. J Exp Med 2004, 200:1337-1346.

52. Raynor CM, Wright JF, Waisman DM, Pryzdial EL: Annexin II enhances cytomegalovirus binding and fusion to phospholipid membranes. Biochemistry 1999, 38:5089-5095

53. LeBouder F, Morello E, Rimmelzwaan GF, Bosse F, Pechoux C, Delmas B, Riteau B: Annexin II incorporated into influenza virus particles supports virus replication by converting plasminogen into plasmin. J Virol 2008, 82:6820-6828

54. Choi J, Chang JS, Song MS, Ahn BY, Park Y, Lim DS, Han YS: Association of hepatitis $B$ virus polymerase with promyelocytic leukemia nuclear bodies mediated by the $\mathrm{S} 100$ family protein $\mathrm{p} 11$. Biochem Biophys Res Commun 2003, 305:1049-1056.

55. Wang J, Jiang D, Zhang H, Lv S, Rao H, Fei R, Wei L: Proteome responses to stable hepatitis $B$ virus transfection and following interferon alpha treatment in human liver cell line HepG2. Proteomics 2009, 9:1672-1682.

56. Fu LY, Jia HL, Dong QZ, Wu JC, Zhao Y, Zhou HJ, Ren N, Ye QH, Qin LX: Suitable reference genes for real-time PCR in human HBV-related hepatocellular carcinoma with different clinical prognoses. $B M C$ Cancer 2009, 9:49.

57. Gao Q, Wang XY, Fan J, Qiu SJ, Zhou J, Shi YH, Xiao YS, Xu Y, Huang XW, Sun J: Selection of reference genes for real-time PCR in human hepatocellular carcinoma tissues. J Cancer Res Clin Oncol 2008, 134:979-986.

58. Cicinnati VR, Shen Q, Sotiropoulos GC, Radtke A, Gerken G, Beckebaum S: Validation of putative reference genes for gene expression studies in human hepatocellular carcinoma using real-time quantitative RT-PCR. BMC Cancer 2008, 8:350.

59. Watson S, Mercier S, Bye C, Wilkinson J, Cunningham AL, Harman AN: Determination of suitable housekeeping genes for normalisation of 
quantitative real time PCR analysis of cells infected with human immunodeficiency virus and herpes viruses. Virol J 2007, 4:130.

60. Radonic A, Thulke S, Bae HG, Muller MA, Siegert W, Nitsche A: Reference gene selection for quantitative real-time PCR analysis in virus infected cells: SARS corona virus, Yellow fever virus, Human Herpesvirus-6, Camelpox virus and Cytomegalovirus infections. Virol I 2005, 2:7.

61. Sun S, Yi X, Poon RT, Yeung C, Day PJ, Luk JM: A protein-based set of reference markers for liver tissues and hepatocellular carcinoma. $B M C$ Cancer 2009, 9:309.

62. Condreay LD, Aldrich CE, Coates L, Mason WS, Wu TT: Efficient duck hepatitis B virus production by an avian liver tumor cell line. J Virol 1990, 64:3249-3258.

63. Jilbert AR, WU TT, England JM, Hall PM, Carp NZ, O'Connell AP, Mason WS: Rapid resolution of duck hepatitis $B$ virus infections occurs after massive hepatocellular involvement. J Virol 1992, 66:1377-1388.

64. Wheeler CH, Dunn MJ, Rheumatology H, London UK, Pharmacia A: A modified silver staining protocol for visualization of proteins compatible with matrix-assisted laser desorption/ionization and electrospray ionization-mass spectrometry. Electrophoresis 2000, 21:3666-3672

doi: 10.1186/1477-5956-8-28

Cite this article as: Zhao et al., Proteomic analysis of primary duck hepatocytes infected with duck hepatitis B virus Proteome Science 2010, 8:28

Submit your next manuscript to BioMed Central and take full advantage of:

- Convenient online submission

- Thorough peer review

- No space constraints or color figure charges

- Immediate publication on acceptance

- Inclusion in PubMed, CAS, Scopus and Google Scholar

- Research which is freely available for redistribution

Submit your manuscript at www.biomedcentral.com/submit 